\title{
Evaluation of fungicides for control of bitter and sprinkler rots on apple fruit
}

\author{
K.R. Everett ${ }^{1}$, I.P.S. Pushparajah ${ }^{1}$, J.T. Taylor ${ }^{2}$, O.E. Timudo-Torrevilla ${ }^{1}$, T.M. Spiers ${ }^{2}$, \\ A. Ah Chee ${ }^{2}$ P.W. Shaw ${ }^{3}$ and D.R. Wallis ${ }^{3}$ \\ ${ }^{1}$ The New Zealand Institute for Plant E Food Research Limited (Plant E Food Research), \\ Mt Albert Research Centre, Private Bag 92169, Auckland 1142, New Zealand \\ ${ }^{2}$ Plant \& Food Research, Ruakura Research Centre, Private Bag 3123, Waikato Mail \\ Centre, Hamilton 3240, New Zealand \\ ${ }^{3}$ Plant E Food Research, Riwaka Research Centre, PO Box 220, Motueka, New Zealand \\ Corresponding author: Kerry.Everett@plantandfood.co.nz
}

\begin{abstract}
Bitter rot is an apple fruit disease most commonly caused in New Zealand by the fungus Colletotrichum acutatum. The timing of fungicide applications to manage this disease was investigated during two seasons. Fungicides applied during October (carbendazim), or November and December (tolyfluanid, captan and mancozeb), reduced incidence of rots expressing on trees in the orchard. Fungicides (half-strength copper oxychloride, Bacillus subtilis QST 713 and tolyfluanid) applied during January and February reduced the incidence of postharvest rots. Bacillus subtilis QST 713 applied regularly throughout the season reduced incidence of field rots, but was not effective when the number of applications was reduced. Calcium chloride $\left(\mathrm{CaCl}_{2}\right)$ or copper oxychloride applied during November and December reduced the incidence of sprinkler rots caused by Phytophthora cactorum.
\end{abstract}

Keywords fungicides, field trials, Colletotrichum acutatum, Phytophthora cactorum, sprinkler rots.

\section{INTRODUCTION}

Summer rot of apples is a general term that has been used in New Zealand to describe a number of different symptom types on fruit, including core rots, mouldy core, wound rots and surface rots (Everett et al. 2007). This study focuses on the disease commonly known as bitter rot that causes lesions on the surface of apple fruit. These lesions begin as small, 1- to 2-mm diameter dark spots, usually on the side of the fruit exposed to the sun, which can enlarge to cover the entire fruit surface with one or several orange, sporulating lesions. Lesions are ' $v$ ' shaped in cross section. Infection eventually results in fruit drop (Sutton 2014).
Historically the causal organism of this disease in New Zealand had been identified as Colletotrichum gloeosporioides (synonym Glomerella cingulata) (Brook 1977). The inoculum sources, infection criteria and means of spread of this fungus were determined, resulting in effective control measures being adopted three decades ago. However, there has been a recent shift to Colletotrichum acutatum as the most common causal organism of bitter rot in apples, probably related to changes in fungicide use (Johnston et al. 2005). Thus historical studies in New Zealand (Brook 1977) and overseas (Sutton 1990), which 
have also focused on C. gloeosporioides as the causal agent of bitter rot, may no longer be relevant to control of this disease.

On occasion, summer rots can be caused by Botryosphaeria dothidea, and somerecommendations for control of summer rots caused by this fungus have been made (Everett et al. 2007).

Another apple disease caused by C. gloeosporioides results in defoliation of apple trees in Brazil and south eastern USA, and is referred to as glomerella leaf spot (GLS) (Carvalho et al. 2000). Although C. acutatum could be isolated from infected apple orchards, pathogenicity tests showed that this fungus did not cause the leaf drop disease (Carvalho et al. 2000; Gonzalez et al. 2006).

More recently, Sutton (2014) reported C. acutatum as a causal organism of bitter rot, but the control strategy relies on applying fungicides at 10- to 14-day intervals throughout the season. Fungicide applications can be targeted, and therefore potentially reduced in number, by using a model for predicting infection periods based on temperature that has been developed for C. gloeosporioides causing GLS in Brazil (Crusius et al. 2002). Because C. gloeosporioides has a different response to temperature from C. acutatum (Everett \& Pak 2002; Everett 2003), this model cannot be used for predicting infection periods for bitter rot in New Zealand.

Despite following a calendar spraying regime as recommended by Sutton (1990), growers in New Zealand have been unable to control bitter rot, resulting in considerable on-orchard and postharvest losses. The present study was initiated to investigate the timing of fungicide applications required to control this disease more effectively. Fungicides with known efficacy against C. acutatum determined in vitro and in the field on avocados (Everett et al. 2005; Everett \& TimudoTorrevilla 2007; Everett et al. 2008; Everett et al. 2011) were tested, along with a commercialised biological control agent with efficacy against C. acutatum (Moreira et al. 2014) and calcium chloride. Calcium chloride was used because of promising activity against C. acutatum in tests on detached apples (Boyd-Wilson \& Walter 2009). The aim was to improve control of bitter rots on apple orchards by applying fungicides at the correct time during the season.

\section{MATERIALS AND METHODS Application to apple trees}

Four fungicide trials were conducted in two regions (Waikato and Nelson) over two growing seasons (2007/8 and 2008/9) on 'Royal Gala' apples to determine the optimal timing to control rots caused by $C$. acutatum. Three 'windows' of applications were tested, spring (October/ early November), early summer (November/ December) and late summer (January/February). Usually four applications were made during each window, except in spring where two to seven applications were made, and one late summer window where, because of rain, only three applications were made.

During the 2007/8 season, applications were made on the Waikato orchard in (1) spring: on $16,23,30$ October 2007 (carbendazim only on 16 and 23 October); (2) early summer: 9, 29 November 2007, 11, 21 December 2007 and (3) late summer: 7, 21 January, 13 and 19 February 2008. On the Nelson Orchard, application dates were (1) spring: 8, 16, 24, 31 October 2007, 7, 15, 26 November 2007 (carbendazim only on 8 and 16); (2) early summer: $5,14,21,28$ December 2007 and (3) late summer: 9, 18, 28 January and 8 February 2008.

During the 2008/9 season, applications were made on the Waikato orchard in (1) spring: on 13, 28 October 2008; (2) early summer: 10, 25 November 2008, 4, 19 December 2008 and (3) late summer: 5, 20 January, 3 and 18 February 2009. Applications on the Nelson Orchard were in (1) spring: 13, 21 October 2008; (2) early summer: 11, 20 November 2008, 1, 11 December 2008 and (3) late summer: 12, 22 January and 16 February 2009.

All treatments were compared with an unsprayed control. Each spray treatment was applied to five replicate trees using a random block design. Different trees within the orchards were used for the 2007/8 and 2008/9 trials. Products were applied to run-off using a pressurised hand-gun sprayer. The fungicides used, the timing, and their respective application rates are detailed in Table 1. 
Table 1 Timing, products used and rates of active ingredients applied to five trees per treatment of 'Royal Gala' apple trees in field trials for control of Colletotrichum acutatum.

\begin{tabular}{|c|c|c|c|}
\hline Product $^{1}$ & Active ingredient (ai) & $\begin{array}{c}\text { Rate } \\
\text { (ai/100 litres) }\end{array}$ & $\begin{array}{l}\text { Treatment number } \\
\text { and timing }\end{array}$ \\
\hline \multicolumn{4}{|l|}{$2007 / 8$} \\
\hline Goldazim $^{\circledR} 500$ SC & carbendazim & $12.5 \mathrm{~g}$ & 1 (spring) \\
\hline Euparen ${ }^{\circledR}$ Multi & tolyfluanid & $50 \mathrm{~g}$ & $\begin{array}{l}2 \text { (spring) } \\
3 \text { (early summer) }\end{array}$ \\
\hline Kocide $^{\circledR} 2000$ & copper hydroxide & $33.25 \mathrm{~g}$ & 4 (late summer) \\
\hline Serenade ${ }^{\circledR}$ Max & Bacillus subtilis QST 713 & $5 \times 10^{8} \mathrm{cfu} / \mathrm{ml}$ & 5 (all season) \\
\hline $74 \%$ flake & calcium chloride & $245 \mathrm{~g}$ & 6 (late summer) \\
\hline \multicolumn{4}{|l|}{$2008 / 9$} \\
\hline Pristine $^{\circledR}$ & pyraclostrobin/boscalid & $22.8 \mathrm{~g}$ & 1 (spring) \\
\hline Euparen ${ }^{\circledR}$ Multi & tolyfluanid & $50 \mathrm{~g}$ & $\begin{array}{l}2 \text { (early summer) } \\
3^{2} \text { (late summer) }\end{array}$ \\
\hline $\begin{array}{l}\text { McGregor's }{ }^{\circledR} \text { copper } \\
\text { oxychloride }\end{array}$ & copper oxychloride & $84 \mathrm{~g}$ & $3^{2}$ (late summer) \\
\hline Serenade ${ }^{\circledR}$ Max & Bacillus subtilis QST 713 & $5 \times 10^{8} \mathrm{cfu} / \mathrm{ml}$ & $\begin{array}{l}4 \text { (spring) } \\
5 \text { (early summer) } \\
6 \text { (late summer) }\end{array}$ \\
\hline Captan 80W & captan & $100 \mathrm{~g}$ & 7 (early summer) \\
\hline Manzate $^{\circledR} 200 \mathrm{DF}$ & mancozeb & $150 \mathrm{~g}$ & 8 (early summer) \\
\hline
\end{tabular}

${ }^{1}$ Euparen is a registered trademark of Bayer CropScience; Goldazim is a Registered Trademark of Chimac-Agriphar, SA; Kocide is a Registered Trademark of Griffin Corporation, USA; Manzate is a Registered Trademark of E I Du Pont de Nemours \& Co Inc; Pristine is a Registered Trademark of BASF New Zealand Limited; Serenade is a Registered Trademark of AgraQuest Inc., USA. Use of a particular product does not endorse this product in preference to other products with the same active ingredient. ${ }^{2}$ Tolyfluanid was applied in late summer in Nelson, and copper oxychloride was applied in late summer in Waikato.

Late summer applications used only fungicides that complied with low residue requirements for apple exports (copper oxychloride, copper hydroxide, $\mathrm{CaCl}_{2}$ and Bacillus subtilis QST 713), except for tolyfluanid on the Nelson orchard in 2008/9. Carbendazim and pyraclostrobin/boscalid were used in spring to test the effectiveness of applying a systemic and a semi-systemic fungicide, respectively, during that period, but were applied only twice. A commercially available biological control agent (Bacillus subtilis QST 713) was applied on every spray date throughout the season in $2007 / 8$, and in spring, early summer or late summer in 2008/9, as well as on 28 October 2008 in Waikato and 6, 31 October 2008 in Nelson. $\mathrm{CaCl}_{2}$ was applied in late summer in 2008 only.
In 2008 the Nelson orchard block was overheadwatered for three out of every seven days from January to February. Water was applied by pulsing ( 5 min on, 6 min off) every hour from 0830 h until $1930 \mathrm{~h}$ starting on 7 January 2008 and finishing on 26 February 2008. In 2009 at the Nelson orchard, an overhead irrigation system was set up and rainfall was simulated for one 72 -h period in early January. Water was applied by pulsing ( $5 \mathrm{~min}$ on, $6 \mathrm{~min}$ off) every hour from $0830 \mathrm{~h}$ until $1930 \mathrm{~h}$ starting on the afternoon for 3 hours on 7 January 2009 and finishing on 9 January 2009. Twelve 'Granny Smith' apples showing symptoms of rots caused by C. acutatum were placed below the canopy of each treated tree on 6 October 2008 only at Nelson to ensure inoculum was present in every plot. 


\section{Disease assessment}

Disease was assessed by labelling ten randomly selected branches per tree and recording the number of infected fruit and lesion sizes at weekly intervals in 2007/8 on six occasions from 15 January to 26 February at the Waikato site and four times on 16, 31 January, 13 and 25 February at the Nelson site; and in 2008/9 on six occasions between 15 January to 23 February at the Waikato site and only postharvest in Nelson as there were too few fruit with symptoms pre-harvest. If there were several lesions on a fruit, then the lesion diameter was summed to give a total surface area affected by bitter rot. Any russet symptoms, which are due to phytotoxicity, were also recorded as incidence data. In 2008/9, 100 fruit per treatment (20 fruit from each of five trees) were placed in the coolstore at $0 \pm 0.5^{\circ} \mathrm{C}$ and assessed following removal after 15 weeks and 7 days at $20^{\circ} \mathrm{C}$.

\section{Isolations}

During 2007/8 season, isolations to identify the fungal pathogens were made from a randomly selected sub-sample of 10 fruit (one to two lesions per fruit) showing symptoms of bitter rot from each of the two sites. The surface of each diseased apple fruit was wiped with $70 \%$ ethanol, the skin was cut and peeled back, and a portion of the exposed rotted tissue excised and placed on Difco ${ }^{\circledR}$ potato dextrose agar. After 3-6 weeks under UV/daylight fluorescent lights on a 12:12 h day:night cycle, any resultant fungi were identified by culture and spore morphology. Isolations were made from two fruit showing symptoms from each region during the 2008/09 season.

\section{Statistical analysis}

MINITAB $^{\circledR}$ (version 12) and Microsoft ${ }^{\circledR}$ Excel were used for data analysis. The tree was the experimental unit for fruit assessments. Tree means at each week were calculated by averaging the lesion diameter measurements over all the fruit. Treatment means and their standard errors were calculated using the tree means weighted by the number of fruit per tree. There were unequal numbers of fruit per branch. Dropouts were handled by Last Observation
Carry Forward (LOCF). This is a method for imputation of missing values (Powers et al. 2007). Incidence data were arcsine transformed before analysis. The last remaining observation is carried through to remaining time points. It is assumed that dropout is due to fruit missing at random. Statistical differences were calculated using Analysis of Variance (ANOVA) followed by mean separation tests using Tukey's Least Significant Difference $(\mathrm{P}<0.05)$ or Dunnet's onetailed $t$ test (generalised linear model functions of MINITAB ${ }^{\circledR}$ ) of the final point response. To ensure that ANOVA assumptions were met, the proportional data were transformed before analysis, using the angular transformation, i.e. $\arcsin (\operatorname{sqrt}(\mathrm{x}))$. Graphs were generated using Microcal ${ }^{\circledR}$ Origin.

\section{RESULTS}

\section{7/8 season}

\section{Waikato}

There were significant differences in the incidence and severity of bitter rot between fruit from treatment 4 (half-strength copper hydroxide applied during late summer) and those from all other treatments (Figures 1a \& 1b). Application of copper hydroxide resulted in significantly more fruit with bitter rot than in the untreated control fruit. When this treatment was removed from the analysis, the incidence of bitter rot in fruit from treatments 1, 2, 3 and 5 (treatments 1 and 2, application of carbendazim and tolyfluanid, respectively, in spring; treatment 3, application of tolyfluanid in early summer; and treatment 5 , application of Bacillus subtilis QST 713 throughout the season) was significantly lower than those in treatments $6\left(\mathrm{CaCl}_{2}\right)$ and 7 (control) (Figure 1a). There were no significant differences in severity of bitter rot between treatments following removal of treatment 4 from the analysis (Figure $1 \mathrm{~b}$ ).

Fruit russet was only significant $(4.7 \%$, $\mathrm{P}=0.05)$ compared to the other treatments (less than $0.5 \%$ ) in treatment 2 (three applications of tolyfluanid in spring).

Colletotrichum acutatum was isolated from all fruit showing bitter rot symptoms from the Waikato orchard. 

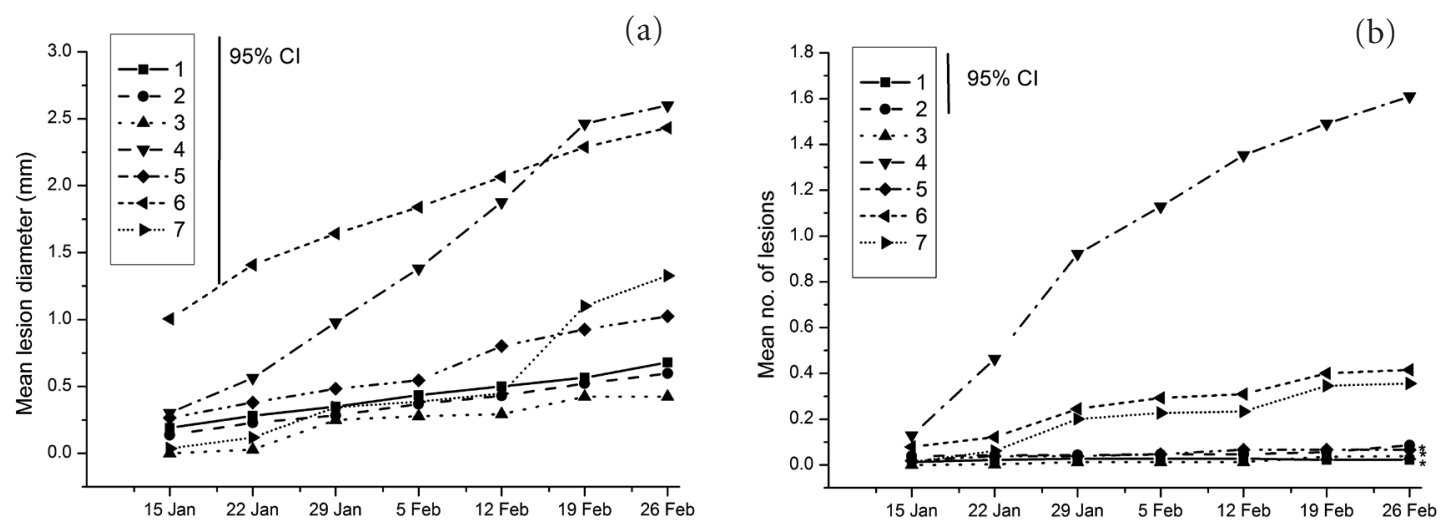

Figure 1 The mean (a) severity (lesion diameter, $\mathrm{mm}$ ) and (b) incidence (number of lesions) of summer rots in fruit from the Waikato 'Royal Gala' apple orchard in the 2007/8 season, for each of the seven treatments: (1) two applications of carbendazim in October, (2) three applications of tolyfluanid in October, (3) four applications of tolyfluanid in November/December, (4) four applications of halfstrength copper hydroxide in January/February, (5) Bacillus subtilis QST 713 from October to February, (6) $\mathrm{CaCl}_{2}$ in January/February and (7) unsprayed control. Incidences of rots in treatments marked by an asterisk were significantly different from that in unsprayed controls following removal of treatment 4 from the analysis $(\mathrm{P}<0.05)$. Bars are Tukey 95\% confidence intervals.

\section{Nelson}

There was no bitter rot observed on the fruit in the overhead-watered block at the Nelson orchard. Instead, a firm diffuse rot that eventually caused fruit to fall from the tree was observed and assessed. Phytophthora cactorum, which causes a disease known as sprinkler rot, was isolated from all fruit showing these symptoms.

Statistical analysis of the incidence of sprinkler

Figure 2 The incidence (arcsine transformed for analysis, but back-transformed for presentation) of sprinkler rots in Nelson 'Royal Gala' apple fruit in the 2007/8 season, for each of the seven treatments:

(1) two applications of carbendazim in October,

(2) seven applications of tolyfluanid in October/ November, (3) four applications of tolyfluanid in December, (4) four applications of half-strength copper in January/February, (5) Bacillus subtilis QST 713 from October to February, (6) $\mathrm{CaCl}_{2}$ in January/February and (7) unsprayed control. Incidences of rots in treatments marked by an asterisk were significantly different from that in unsprayed controls $(\mathrm{P}<0.05)$. rots showed that fruit from treatments 2 (seven applications of tolyfluanid in spring), 4 (four applications of half-strength copper hydroxide in late summer) and $6\left(\mathrm{CaCl}_{2}\right.$ in late summer $)$ had significantly fewer rots than fruit from untreated controls and from treatments 1 (two applications of carbendazim in spring), 3 (four applications of tolyfluanid in early summer) and 5 (Bacillus subtilis QST 713 throughout the season) (Figure 2).

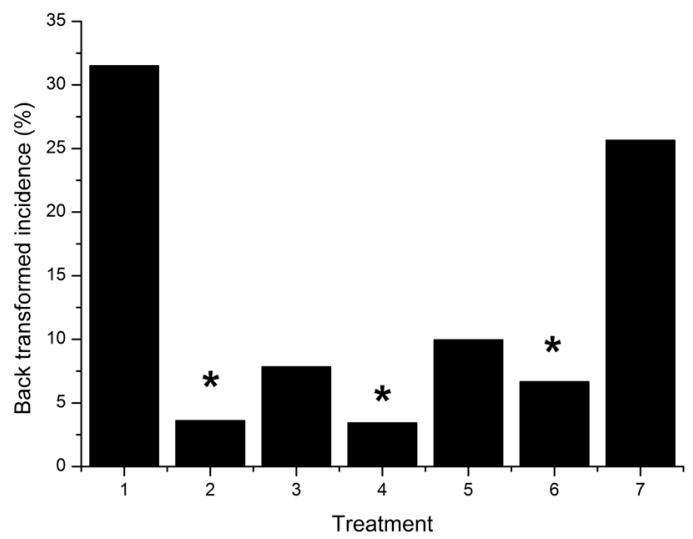




\section{8/9 season}

Waikato

All fungicides applied on four occasions in early summer (November and December) provided some reduction of bitter rot, as measured on orchards, in the spray trial carried out in the Waikato region (Figure 3). However, only captan and mancozeb provided statistically significant $(\mathrm{P}<0.05)$ control of bitter rot severity (Figure 3a; lesion diameter), and captan, mancozeb, pyraclostrobin/boscalid and tolyfluanid of bitter rot incidence (Figure 3b; lesion number). Neither copper oxychloride nor Bacillus subtilis QST 713 applied during late summer (January and February), or Bacillus subtilis QST 713 applied in spring (October), controlled bitter rot.

Copper oxychloride applied at half strength four times during late summer (January and February) reduced severity (Figure $4 \mathrm{a}$ ) and incidence (Figure $4 \mathrm{~b} ; \mathrm{P}<0.05$ ) of postharvest bitter rot. Both Bacillus subtilis QST 713 applied during this time, and mancozeb applied during early summer (November and December), provided statistically significant reduction of incidence and severity, but to a lesser extent than copper. Colletotrichum acutatum was isolated from all fruit showing bitter rot symptoms from the Waikato orchard.

\section{Nelson}

There were too few fruit affected by bitter rot, as measured on orchards, in the spray trial in Nelson for there to be any significant differences between treatments.

Tolyfluanid applied four times during late summer (January and February) provided statistically significant reduction $(\mathrm{P}<0.05)$ of severity (Figure $5 \mathrm{a}$ ) and incidence (Figure $5 \mathrm{~b}$ ) of postharvest bitter rot. However, $3 \%$ of these fruit were affected by russet, which was significantly greater than the amount in the untreated control fruit $(0.7 \%)$. Colletotrichum acutatum was isolated from all fruit showing bitter rot symptoms from the Nelson orchard.
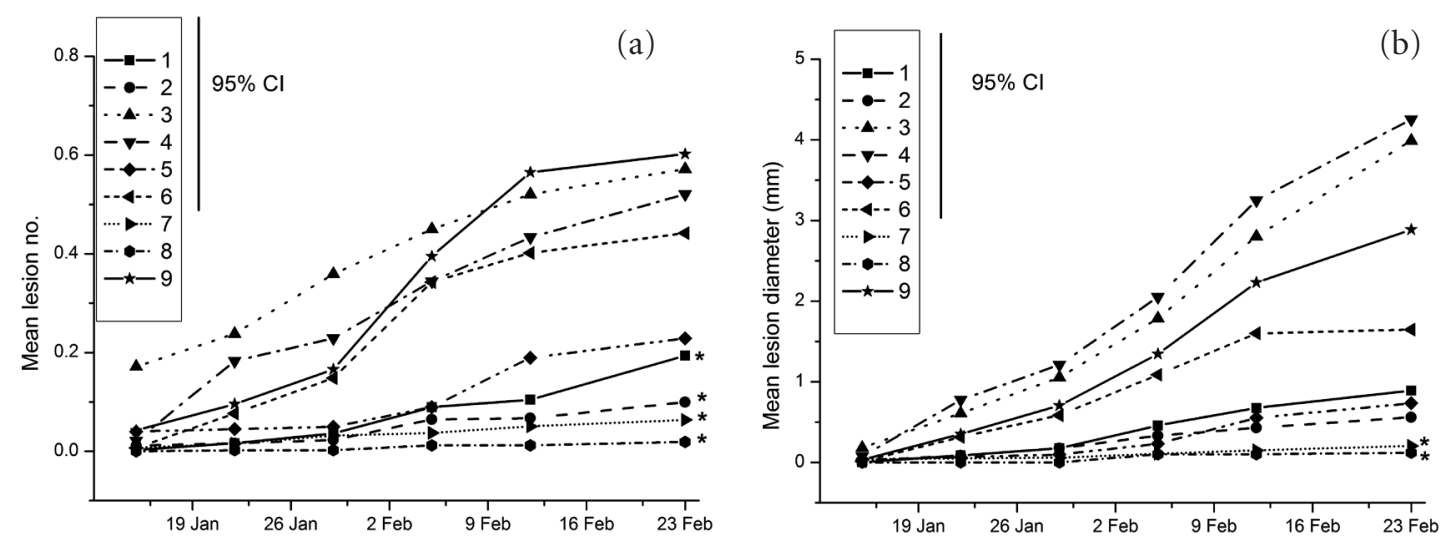

Figure 3 The mean (a) severity and (b) incidence of summer rots in fruit from the Waikato 'Royal Gala' apple orchard in the 2008/9 season, for each of the nine treatments: (1) two applications of pyraclostrobin/boscalid in October, (2) four applications of tolyfluanid in November/December, (3) four applications of half-strength copper oxychloride in January/February, (4) three applications of Bacillus subtilis QST 713 in October, (5) four applications of Bacillus subtilis QST 713 in November/ December, (6) four applications of Bacillus subtilis QST 713 in January/February, (7) four applications of captan in November/December, (8) four applications of mancozeb in November/December and (9) unsprayed control. Incidences of rots in treatments marked by an asterisk were significantly different from that in unsprayed controls $(\mathrm{P}<0.05)$. Bars are Tukey $95 \%$ confidence intervals. 

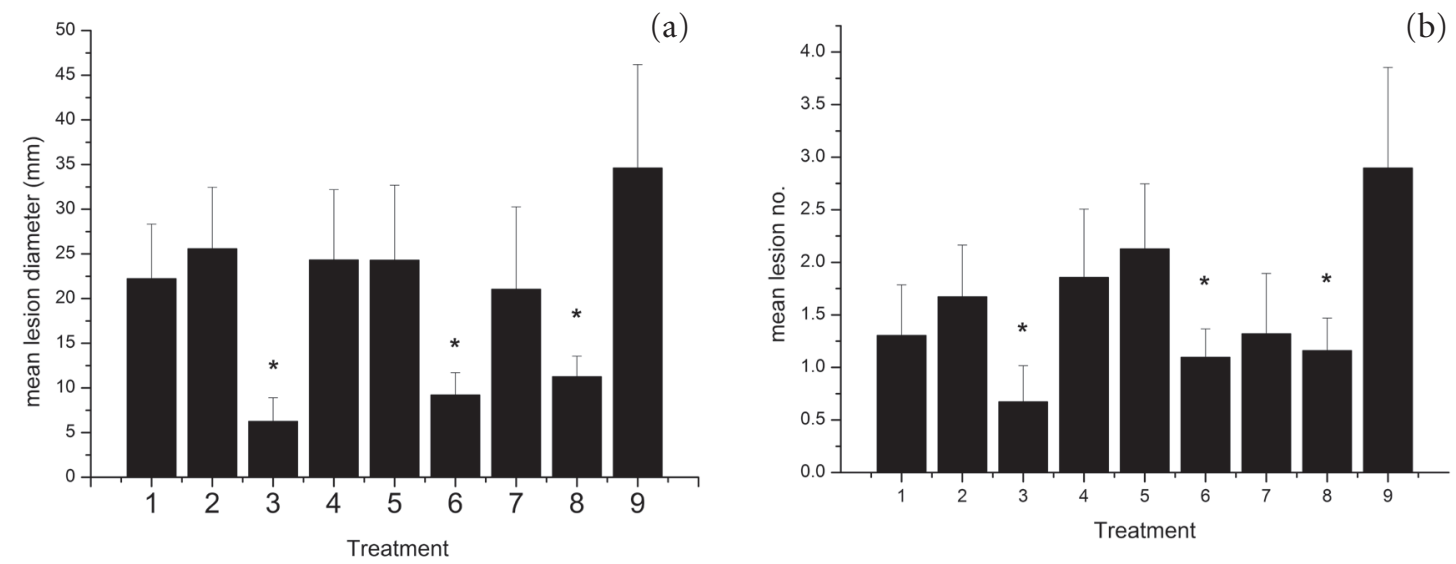

Figure 4 The mean (a) severity and (b) incidence of summer rots in fruit from the Waikato 'Royal Gala' apple orchard in the $2008 / 9$ season, after 15 weeks of storage at $0.5^{\circ} \mathrm{C}$ followed by 7 days at $20^{\circ} \mathrm{C}$ for each of the nine treatments: (1) two applications of pyraclostrobin/boscalid in October, (2) four applications of tolyfluanid in November/December, (3) four applications of half-strength copper oxychloride in January/ February, (4) three applications of Bacillus subtilis QST 713 in October, (5) four applications of Bacillus subtilis QST 713 in November/December, (6) four applications of Bacillus subtilis QST 713 in January/ February, (7) four applications of captan in November/December, (8) four applications of mancozeb in November/December and (9) unsprayed control. Incidences of rots in treatments marked by an asterisk were significantly different from that in unsprayed controls $(\mathrm{P}<0.05)$.Values are means \pm standard errors.
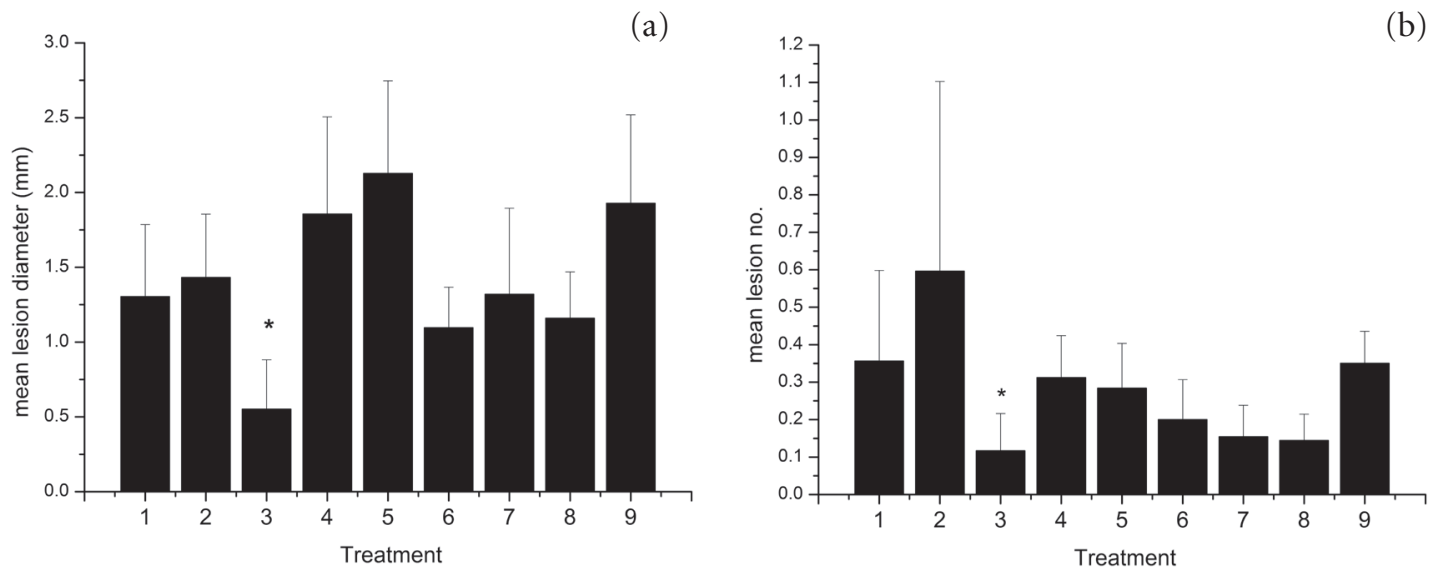

Figure 5 The mean (a) severity and (b) incidence of summer rots in fruit from the Nelson 'Royal Gala' apple orchard in the $2008 / 9$ season, after 15 weeks of storage at $0.5^{\circ} \mathrm{C}$ followed by 7 days at $20^{\circ} \mathrm{C}$ for each of the nine treatments: (1) two applications of pyraclostrobin/boscalid in October, (2) four applications of tolyfluanid in November/December, (3) three applications of tolyfluanid in January/February, (4) four applications of Bacillus subtilis QST 713 in October, (5) four applications of Bacillus subtilis QST 713 in November/December, (6) three applications of Bacillus subtilis QST 713 in January/February, (7) four applications of captan in November/December, (8) four applications of mancozeb in November/ December and (9) unsprayed control. Incidences of rots in treatments marked by an asterisk were significantly different from that in unsprayed controls $(\mathrm{P}<0.05)$. Values are means \pm standard errors. 


\section{DISCUSSION}

Tolyfluanid and carbendazim applied in spring 2007 were able to control orchard expression of bitter rot during the 2007/8 season in Waikato. However, pyraclostrobin/boscalid applied in spring during the 2008/9 season did not provide statistically significant reduction of rots, despite in vitro efficacy against C. acutatum (Everett \& Timudo-Torrevilla 2007), suggesting that infections did not occur in spring during that season. When compared with untreated controls, some reduction in incidence and severity of rots was achieved, possibly because of the persistence of this fungicide preventing some later infections.

The ability of carbendazim, applied during this period, to control rots may be due to greater persistence of this fungicide than of pyraclostrobin/boscalid, allowing it to remain active to protect the fruit from infections occurring later in the season. This is supported by the results of residue testing for carbendazim in kiwifruit (McKenna et al. 2012), which, when applied during flowering (30 October) could still be detected in fruit at harvest three months later (February 10). On apples, carbendazim residues were detected in fruit by chemical assay for up to 35 days after application of four sprays at 10-day intervals, and by bioassays it remained efficacious against apple scab (Venturia inaequalis) 15 days after application (Sharma \& Bharat 1994). In contrast, pyraclostrobin/boscalid did not persist for this length of time when applied to spring onions in the field. On this crop, pyraclostrobin was undetectable after 14 days, and the halflife for boscalid was determined to be 8.5 days (Hanafi et al. 2010). Testing on apples is required to support this hypothesis.

Except for Bacillus subtilis QST 713, all fungicides (tolyfluanid, mancozeb and captan) applied in early summer during the 2008/9 season in Waikato were able to control rot symptoms caused by C. acutatum in the field. These results also suggest that infections did not occur in spring. Because Bacillus subtilis QST 713 applied in late summer was able to protect fruit from postharvest rots, failure of control when it was applied in early summer suggests that infection for rots that expressed in the orchard occurred in late summer. The ability of captan, tolyfluanid and mancozeb applied in early summer to protect the fruit from these infections was probably because of their greater persistence compared with that of Bacillus subtilis QST 713.

This hypothesis is supported by other studies, where there is some evidence that the fungicides may have persisted in the field for a greater length of time than did Bacillus subtilis QST 713. For example, captan could be detected in 'Jonathan' apples 15 days after application (Pogãcean et al. 2014), and could remain active against $V$. inaequalis on apple foliage and fruit for 7 days after application despite simulated rainfall (Smith \& MacHardy 1984). Mancozeb persisted for an even longer period. On potato leaves, mancozeb was detected 15 days after application (Wani 2012); on apple leaves mancozeb persisted for 10 days (Sharma \& Garg 1990) and in another study for 30 days (Sharma \& Nath 2005). Tolyfluanid was detected on apple skins 18 days after application (Rasmusssen et al. 2003). In contrast, a related bacterium used for biological control, Bacillus licheniformis $\mathrm{N} 1$, persisted on tomato plants in glasshouse conditions only for 5 days (Kong et al. 2010). If the infection period was greater than 5 days after cessation of the early summer applications, it is feasible that captan, mancozeb and tolyfluanid would have protected the apples but Bacillus subtilis QST 713 may not have.

Only mancozeb applied early summer and application of copper oxychloride or Bacillus subtilis QST 713 in late summer were able to control bitter rot that developed postharvest. These results suggest that only mancozeb applied in early summer 2008 was able to remain active long enough to protect fruit from infections that took place in late summer (January/February), and expressed later as postharvest storage rots.

The timing of fungicide applications to control bitter rot caused by C. acutatum generally concur with those required for bitter rot caused by Botryosphaeria dothidea, which also required applications in early and late summer for control (Everett et al. 2007). However, carbendazim applications during flowering did not control 
summer rots caused by Botryosphaeria dothidea. For carbendazim to have lost activity, a very late infection period for this fungus may have occurred, but it is more likely that this fungicide is not as efficacious against Botryosphaeria dothidea. In in vitro tests, benomyl, a fungicide with the same mode of action as carbendazim, failed to inhibit spore germination of an isolate of Botryosphaeria dothidea from avocados, yet effectively inhibited spore germination of $C$. acutatum (Everett et al. 2005) suggesting that failure of control was probably due to lack of efficacy.

Copper hydroxide should not be used for control of apple bitter rot because application resulted in significantly more bitter rot than in untreated controls, suggesting that this formulation at the rates used may have damaged the apple skin, allowing easier entry of the pathogen. In contrast, copper applied in the form of copper oxychloride was able to protect fruit effectively from rots that developed during coolstorage. Therefore, only late summer application of copper in the form of copper oxychloride can be recommended from the results of these trials.

Although unintended, results from the spray trials in Nelson have provided information for control of sprinkler rots that have not been reported previously. Infections appeared to have occurred during late summer (January/ February), and a fungicide (copper oxychloride) and calcium chloride applied during this time provided good control. Calcium chloride is a relatively benign chemical not usually considered a fungicide. Earlier applications of tolyfluanid (seven applications in spring) were sufficient to provide good control during this late infection period, whereas four applications in early summer were not sufficient. The higher number of applications in spring may have ensured that enough tolyfluanid remained on the surface of the fruit to prevent infection later in the season. It is not unexpected that carbendazim applied during spring did not provide any control of sprinkler rots, because this fungicide has no reported activity against Phytophthora cactorum. Recommendations for control currently include modifying the overhead irrigation to a dripper system and adding copper to the irrigation water (Covey et al. 2014). Avoiding overhead irrigation is an effective and simple way to control these rots, but if this is not possible then application of copper oxychloride or $\mathrm{CaCl}_{2}$ during late summer should provide some control.

The recommendations for control of bitter rots that can be made from this study cannot include tolyfluanid, as this chemical has recently been removed from the European market because of concerns regarding nitrosamine breakdown products, which are harmful to human health, contaminating ground water (Barroso 2010).

However, carbendazim applied during flowering, or captan, mancozeb or Bacillus subtilis QST 713 applied from early summer to harvest, should be sufficient to protect fruit from bitter rot as shown during these studies. Application of copper oxychloride as an alternative to mancozeb in late summer is recommended to prevent problems with residues in the marketplace. Application of fungicides in early summer may cause russet problems in sensitive varieties. There is some evidence to suggest that only application in late summer (January to February) is necessary in some seasons.

Further work is required to determine the infection criteria, so that the seasons in which early summer spraying is not necessary can be identified. This may provide a considerable improvement over the currently recommended practice of calendar spraying throughout the season (Sutton 2014). The failure to control bitter rot by New Zealand growers prior to this work may have been due to use of inadequate controls during late summer because of concerns about residues. Late-season applications of captan, Bacillus subtilis QST 713 or copper oxychloride are allowed under current regulations.

\section{ACKNOWLEDGEMENTS}

This study was supported by a grant from the MPI Sustainable Farming Fund, the Waikato Fruitgrowers' Association, Nelson Group 8, Pipfruit New Zealand and Sunfruit Orchards. 


\section{REFERENCES}

Barroso JM 2010. Commission Directive 2010/20/EU. Official Journal of the European Union. http://faolex.fao.org/ docs/pdf/eur93149.pdf (accessed 9 March 2015).

Boyd-Wilson KSH, Walter M 2009. The effects of calcium chloride and calcium carbonate on germination and growth of Colletotrichum acutatum and Penicillium expansum. 17th Biennial Australasian Plant Pathology Society Conference. Newcastle, New South Wales, Australia. p. 36 (abstract only).

Brook PJ 1977. Glomerella cingulata and bitter rot of apple. New Zealand Journal of Agricultural Research 20: 547-555.

Carvalho FMS, Leite Junior RP, Ueno B 2000. Pathogenic characterization of Colletotrichum spp. associated with apple diseases in Southern Brazil. Fitopatologia Brasileira 25: 72-78.

Covey RPJ, Harris DC, Cox K 2014. Phytophthora fruit rot. In: Sutton TB, Aldwinckle HS, Agnello AM, Walgenbach JF ed. Compendium of apple and pear diseases and pests. Second edition. The American Phytopathological Society, St Paul, Minnesota, USA. Pp. 41-42.

Crusius LU, Forcelini CA, Sanhueza RMV, Fernandes JMC 2002. Epidemiology of apple leaf spot. Fitopatologia Brasileira 27: 65-70.

Everett KR 2003. The effect of low temperatures on Colletotrichum acutatum and Colletotrichum gloeosporioides, fungi causing body rots of avocado in New Zealand. Australasian Plant Pathology 32: 441-448.

Everett KR, Pak HA 2002. Infection criteria for pathogens causing body rots in avocados. In: NZ Avocado Growers' Association Annual Research Report. www.avocadosource.com (accessed 9 March 2015). Pp. 54-58.

Everett KR, Timudo-Torrevilla OE 2007. In vitro fungicide testing for control of avocado fruit rots. New Zealand Plant Protection 60: 99-103.

Everett KR, Owen SG, Cutting JGM 2005. Testing efficacy of fungicides against postharvest pathogens of avocado (Persea americana cv. Hass). New Zealand Plant Protection 58: 89-95.
Everett KR, Timudo-Torrevilla OE, Taylor JT, Yu J 2007. Fungicide timing for control of summer rots of apples. New Zealand Plant Protection 60: 15-20.

Everett KR, Timudo-Torrevilla OE, Hill GN, Dawson TE 2008. Field testing alternatives to copper for controlling avocado fruit rots. New Zealand Plant Protection 61: 65-69.

Everett KR, Pak HA, Pushparajah IPS, Taylor JT, Astill MS, King DB, Chee AA 2011. Field evaluation of fungicides to control postharvest rots of avocados in New Zealand. New Zealand Plant Protection 64: 112-118.

Gonzalez E, Sutton TB, Correll JC 2006. Clarification of the etiology of Glomerella leaf spot and bitter rot of apple caused by Colletotrichum spp. based on morphology and genetic, molecular, and pathogenicity tests. Phytopathology 96: 982-992.

Hanafi A, Garau VL, Caboni P, Sarais G, Cabras P 2010. Minor crops for export: A case study of boscalid, pyraclostrobin, lufenuron and lambdacyhalothrin residue levels on green beans and spring onions in Egypt. Journal of Environmental Science and Health, Part B 45: 493-500.

Johnston PR, Pennycook SR, Manning MA 2005. Taxonomy of fruit-rotting fungal pathogens: what's really out there? New Zealand Plant Protection 58: 42-46.

Kong HG, Lee HJ, Bae JY, Kim NH, Moon BJ, Lee S-W 2010. Spatial and temporal distribution of a biocontrol bacterium Bacillus licheniformis $\mathrm{N} 1$ on the strawberry plants. Plant Pathology Journal 26: 238-244.

McKenna CE, Fullerton RA, Dobson SJ, Jia Y 2012. Control of flyspeck (Schizothyrium pomi) on Actinidia arguta kiwifruit. New Zealand Plant Protection 65: 213-217.

Moreira RR, Nesi CN, May De Mio LL 2014. Bacillus spp. and Pseudomonas putida as inhibitors of the Colletotrichum acutatum group and potential to control Glomerella leaf spot. Biological Control 72: 30-37.

Pogãcean MO, Hlihor RM, Gavrilescu M 2014. Monitoring pesticides degradation in apple fruits and potential effects of residues on human health. Journal of Environmental Engineering and Landscape Management 22: 171-182. 
Powers PS, Bannon Y, Eubanks R, McCormick $\mathrm{T}$ 2007. Quetiapine in anorexia nervosa patients: an open label outpatient pilot study. International Journal of Eating Disorders 40 21-26

Rasmusssen RR, Poulsen ME, Hansen HCB 2003. Distribution of multiple pesticide residues in apple segments after home processing. Food Additives \& Contaminants 20: 1044-1063.

Sharma ID, Nath A 2005. Persistence of different pesticides in apple. Acta Horticulturae 696: 437-440.

Sharma SK, Garg RC 1990. Persistence of fungicides on apple foliage. Plant Disease Research 5: 223-223.

Sharma SK, Bharat NK 1994. Persistence of carbendazim on apple fruit and leaves. Plant Disease Research 9: 204-206.
Smith FD, MacHardy WE 1984. The retention and redistribution of captan on apple foliage. Phytopathology 74: 894-899.

Sutton TB 1990. Bitter rot. In: Jones AL, Aldwinckle HS ed. Compendium of Apple and Pear Diseases. American Phytopathological Society, St. Paul, MN.

Sutton TB 2014. Bitter rot. In: Sutton TB, Aldwinckle HS, Agnello AM, Walgenbach JF ed. Compendium of apple and pear diseases and pests. Second edition. The American Phytopathological Society, St. Paul, Minnesota, USA. Pp. 20-21.

Wani AA 2012. Persistence of metalaxyl and mancozeb on potato leaves and their residues in tubers. Pakistan Journal of Biological Sciences 15: 44-48. 